\title{
Holocene Oscillations in the Temperature and Salinity of the Surface Subpolar North Atlantic
}

David J.R. Thornalley ${ }^{1,2}$, Harry Elderfield ${ }^{1} \&$ I. Nick McCave ${ }^{1}$

1. The Godwin Laboratory for Palaeoclimate Research, Department of Earth Sciences, University of Cambridge, Downing Street, Cambridge, CB2 3EQ, UK.

2. Present address: School of Earth and Ocean Sciences, Cardiff University, Main Building, Park Place, Cardiff, CF10 3YE, UK. 
The Atlantic meridional overturning circulation (AMOC) transports warm salty surface waters to high latitudes, where they cool, sink, and return southwards at depth. Through its attendant meridional heat transport, the AMOC helps maintain a warm NW European climate, and acts as a control on global climate. Past climate fluctuations during the Holocene (0-11.7 ka) have been linked with changes in North Atlantic Ocean circulation ${ }^{1,2}$. However, the behavior of the surface flowing salty water that helps drive overturning is not well-known during past climate change. Here we investigate the temperature and salinity changes of a major surface inflow to a region of deepwater formation throughout the Holocene. The inflow has undergone millennial variations in temperature and salinity $\left(\sim 3.5^{\circ} \mathrm{C}\right.$ and $\left.\sim 1.5 \mathrm{psu}\right)$ controlled by subpolar gyre dynamics. These variations correlate with previously reported periods of rapid climate change ${ }^{3}$. The inflow becomes more saline during enhanced freshwater flux to the subpolar North Atlantic. Models predict a weakening of AMOC in response to enhanced Arctic freshwater fluxes ${ }^{4}$, although the inflow can compensate on decadal timescales by becoming more saline ${ }^{5}$. We provide evidence for the operation of this negative feedback during past intervals of climate change.

The AMOC is a critical component of the Earthôs climate system, redistributing heat and partitioning carbon between the surface and deep ocean reservoirs. The surface limb of the AMOC consists of the warm, saline, surface North Atlantic Current (NAC) that flows north-eastwards across the North Atlantic into the Nordic Seas (hereafter referred to as the Inflow), passing between the subpolar and subtropical gyres, from which it draws water ${ }^{6}$ (Fig. 1). Upon entering the Nordic Seas, cooling promotes the formation of deep water, which overflows the Greenland-Scotland Ridge and returns southwards as a major component of North Atlantic Deep Water ${ }^{6} \ddot{i}$ the deep water limb of the AMOC. Here we investigate the hydrography of the Inflow throughout the 
Holocene, a period which includes enhanced freshwater fluxes before 8 ka due to ice sheet disintegration.

The Holocene has experienced considerable climatic variability on decadal ${ }^{6,7}$ to millennial ${ }^{1,2,8,9}$ timescales, notwithstanding the rather constant isotopic record in the Greenland ice cores ${ }^{10}$. Instrumental, historical and proxy data have documented rapid and large changes in the position of the subpolar front (intra-annual fluctuations of up to $300 \mathrm{~km}$ and millennial excursions of up to $500 \mathrm{~km}$ ), bringing cold, fresh, ice-bearing waters to the coasts of Iceland ${ }^{6,79}$ These climatic fluctuations are linked with important cultural and socio-economic changes throughout NW Europe ${ }^{9}$ and via teleconnections, globally ${ }^{3}$.

We reconstruct the temperature and salinity of the Inflow using paired $\mathrm{Mg} / \mathrm{Ca}-\delta^{18} \mathrm{O}$ measurements on two species of planktonic foraminifera, Globigerina bulloides and Globorotalia inflata, following the procedures of Barker et al. ${ }^{11}$. The oxygen isotopic composition of planktonic foraminiferal calcite depends upon both calcification temperature and the ambient seawater $\delta^{18} \mathrm{O}\left(\delta^{18} \mathrm{O}_{\mathrm{sw}}\right)$. The $\mathrm{Mg} / \mathrm{Ca}$ ratio of planktonic foraminiferal calcite is controlled primarily by calcification temperature ${ }^{12}$. Combined $\mathrm{Mg} / \mathrm{Ca}-\delta^{18} \mathrm{O}$ measurements therefore allow the reconstruction of temperature and $\delta^{18} \mathrm{O}_{\mathrm{sw}}$; paleo-salinity can then be estimated using modern $\delta^{18} \mathrm{O}_{\text {sw }}$ salinity relationships, although the $\delta^{18} \mathrm{O}_{\text {sw }}$ salinity relationship is uncertain through time (see Methods Summary for errors $)^{13}$. By examining species with different depth-habitats, reconstructions can sample both the surface and volumetrically significant waters below. The stable isotope composition of both species reflect conditions during late Spring/early Summer ${ }^{14} . G$. bulloides occupies the seasonal mixed layer, typically $0-50 \mathrm{~m}^{14}$. G. inflata calcifies at the base of the seasonal thermocline, ${ }^{15}(\sim 100-200 \mathrm{~m}),{ }^{14}$ in waters cooled during winter convection. Shallow temperature and salinity gradients below the thermocline may reduce the impact of habitat depth migration on G.inflata based reconstructions. 
Records were made using sediment core RAPiD-12-1K (62 $05.43 \widehat{\alpha}, 17^{\circ} 49.18 \mathrm{~W}$; $1938 \mathrm{~m}$ water depth) from the South Iceland Rise (Fig. 1). Sedimentation rates average $115 \mathrm{~cm} / \mathrm{ka}$ from 12 to $8 \mathrm{ka}$ and $23 \mathrm{~cm} / \mathrm{ka}$ from $8 \mathrm{ka}$ to the present (dated by ${ }^{14} \mathrm{C}$ accelerator mass spectrometry (Supplementary Methods)). The core lies under the path of the NAC where it bifurcates to form the Irminger and Faroe Currents ${ }^{16}$, although instrumental and historical records also document episodes of cold ice-bearing subpolar waters from the north reaching the site ${ }^{7,9}$. Modern hydrographic measurements indicate a well mixed upper water column down to at least $600 \mathrm{~m}$, with a nearly constant salinity of $35.2 \mathrm{i} 35.3 \mathrm{psu}$ and temperature of $\sim 8^{\circ} \mathrm{C}$, and seasonal warming of the upper $50-100 \mathrm{~m}$ to $11.5{ }^{\circ} \mathrm{C}^{17}$.

The $\mathrm{Mg} / \mathrm{Ca}$ and $\delta^{18} \mathrm{O}$ data for $G$. bulloides reveal millennial salinity variations of $\sim 0.5$ psu superimposed upon a trend of increasing near-surface water salinity from $\sim 9 \mathrm{ka}$ to the present (Fig. 2). Temperatures remain nearly constant at $10-11{ }^{\circ} \mathrm{C}$ reflecting a similar seasonal warming of near-surface waters. The early Holocene between $11 \mathrm{ka}$ and $8 \mathrm{ka}$ is characterized by low salinities, fluctuating around $\sim 34 \mathrm{psu}$. The longer timescale trends in near surface salinity are consistent with nearby $\mathrm{Mg} / \mathrm{Ca}$ based near-surface salinity reconstructions ${ }^{8}$, which may be caused by some or all of: net Atlantic Ocean salinity changes related to the gradual migration of the Inter Tropical Convergence Zone ${ }^{18}$; early Holocene input of light $\delta^{18} \mathrm{O}_{\mathrm{sw}}$ deglacial meltwater to the North Atlantic ${ }^{8}$; changes in freshwater export from the Arctic Ocean. Centennial to millennial freshening of the near-surface water most likely reflects the southward advance of the subpolar front, as in the 1960s when atmospheric changes (North Atlantic Oscillation minimum conditions) resulted in more northerly winds exporting sea-ice southwards from the Nordic Seas ${ }^{7}$. In response to surface freshening, it is possible that G. bulloides migrated to a deeper, more saline, environment and the freshening is underestimated.

During the early Holocene the sub-thermocline (G. inflata) data show that temperatures were similar to the fresh near-surface layer but salinity was greater. 
Between $9 \mathrm{ka}$ and $8 \mathrm{ka}$, strong sub-thermocline cooling and freshening occurred so that between $8 \mathrm{ka}$ and $7 \mathrm{ka}$ the upper water column structure was similar, but fresher, compared to the modern. During this transition, the $8.2 \mathrm{ka}$ glacial freshwater discharge event can be recognized as a 0.5 psu sub-thermocline freshening, similar in amplitude to previous studies ${ }^{8}$. Sub-thermocline temperature and salinity oscillate throughout the remainder of the Holocene. Warm saline sub-thermocline conditions are centered at 0.3, 1.0, 2.7 and $5.0 \mathrm{ka}$, coinciding with known climatic perturbations in the North Atlantic region e.g., the Little Ice Age and the 2.7 ka cold event (Fig. 2).

Modern controls on regional salinity identified by Hátún et al. ${ }^{5}$ include: (i) local airsea fluxes of freshwater; (ii) variations in salinity of the subpolar gyre (SPG); or (iii) the subtropical gyre (STG); and (iv) dynamic changes in the relative contributions from the two gyres. Mechanism (i) does not explain the sub-thermocline changes because air-sea fluxes typical for this region ${ }^{6}$ would cause a much steeper temperature-salinity gradient than measured (Supplementary Discussion). Furthermore, since the upper water column properties are set at source and during advection across the North Atlantic basin, the magnitude of the salinity variations observed would require extreme changes in air-sea fluxes in the Caribbean and over the entire northern North Atlantic. Mechanism (ii) is not responsible because salinity estimates from the Labrador Sea ${ }^{19}$, located within the SPG show fresh conditions in contrast to the saline conditions south of Iceland. Mechanism (iii) is of potential importance considering the amplitude of subsurface STG salinity variability over the last 110 years $^{20}$. However, there is no significant correlation between our south Iceland record and STG salinity records; namely (a) late Holocene Florida Current surface salinity records ${ }^{21}$, and (b) Holocene $\mathrm{Mg} / \mathrm{Ca}-\delta^{18} \mathrm{O}$ based salinity estimates for STG Mode waters, derived from the deep dwelling foraminifer, $G$. truncatulinoides $^{22}$. Further confirmation that mechanism (iii) is not a significant factor will require additional subsurface STG salinity records to be produced. 
Consistent with modern mechanisms ${ }^{5}$, we conclude that throughout the Holocene, the salinity of water below the near-surface layer south of Iceland is primarily controlled by the proportion of water being drawn from either the cold fresh subpolar or warm saline subtropical gyre which has been shown to depend strongly on the dynamics of the $\mathrm{SPG}^{4}$. Strong (weak) SPG circulation strength results in a more East-West (North-South) shaped SPG which therefore contributes more (less) water to the Atlantic Inflow, making it fresher (saltier). The strength of the SPG circulation can depend upon both the local wind stress and/or the baroclinic circulation driven by buoyancy forcing (associated with deep convection) ${ }^{23}$. Freshwater input to the Labrador Sea prevents deep convection ${ }^{24}$, thereby reducing SPG circulation and the SPG influence south of Iceland.

Figure 3 illustrates that existing records are consistent with the SPG strength mechanism: fresh surface conditions in the Labrador Sea ${ }^{19}$ coincide with a reduced influence of the SPG in the eastern subtropical North Atlantic ${ }^{25}$, and more saline conditions south of Iceland. These changes occur during recognized periods of global rapid climate change, involving ocean and atmosphere reorganizations ${ }^{3}$. Early Holocene freshening of the Labrador Sea was likely driven by deglacial meltwater input, and/or enhanced freshwater flux, via the East Greenland Current, during more meridional atmospheric circulation ${ }^{26}$. Late Holocene saline intervals south of Iceland, which indicate weak SPG circulation, are not accompanied by changes in Labrador Sea salinity. This suggests weakened SPG circulation may have been caused by decreased wind stress, rather than enhanced freshwater flux. Late Holocene freshening in the Labrador Sea was possibly also less pervasive and of shorter duration, and thus not recorded by dinocyst assemblages $^{19}$.

Critically, all periods of enhanced surface freshening in the Labrador Sea are accompanied by more saline conditions south of Iceland. SPG dynamics can therefore act as a negative feedback, stabilizing the AMOC to freshwater input. The potential importance of SPG dynamics on the AMOC can be illustrated by examining a recent 
modeling study of Holocene AMOC variability ${ }^{27}$. In this study, millennial oscillations of the AMOC are caused by convective shutdown in the Labrador Sea, and its upstream surface water linkage to the Nordic Seas ${ }^{27}$. Paleoceanographic reconstructions show that convective shutdown has occurred on several occasions throughout the Holocene ${ }^{24}$. This will have reduced SPG circulation strength, producing a more saline Atlantic Inflow to the Nordic Seas, which eventually feeds through to the Labrador Sea (via the East Greenland Current) and restarts convection. Schulz et al. ${ }^{27}$ have proposed that these oscillations may have been controlled by a weak external driver such as solar variability. Weakening of the AMOC has been suggested at 6-5 ka and $2.8 \mathrm{ka}$, during southward advance of sea-ice and a change in atmospheric circulation ${ }^{28}$. The increased salinity of the Inflow observed during these periods may have limited the reduction, or helped restart stronger AMOC.

Holocene variability in Inflow properties, and the southward migration of the subpolar front, cause fluctuating upper water column density stratification south of Iceland (Fig. 2). The records show a stratified upper ocean during the early Holocene with an abrupt switch to well mixed waters at $\sim 8.4 \mathrm{ka}$, followed by quasi-periodic stratification events every $\sim 1500$ years. This suggests that surface circulation was fixed in one mode of operation prior to $\sim 8.4 \mathrm{ka}$, perhaps due to the deglacial input of meltwater to the SPG. Later, with reduced freshwater input, the system oscillated between two modes of operation, involving strong and weak SPG circulation. This threshold behavior is similar to that displayed by the model of Schulz et al. ${ }^{27}$. Spectral analysis of the density stratification record from 8.4 ka to present, using confidence limits of $90 \%$, shows one broad peak centered at 1500 years (Supplementary Notes), consistent with other North Atlantic studies ${ }^{1,2}$. This cyclicity has been attributed to ocean dynamics ${ }^{29}$ and the data here confirm that oceanic factors underlie the oscillations.

The importance of the salinity balance in the North Atlantic is well established, with the transfer of subtropical salinity to high latitudes invoked to precondition and help 
restart deep overturning during rapid climate fluctuations ${ }^{30}$. The Atlantic Inflow is of paramount importance in the transport of salt from low to high latitudes. We have shown that this transport has undergone large amplitude millennial variability modulated by SPG dynamics. Although further confirmation of this mechanism will require additional subsurface North Atlantic salinity records, this critical process should be included when examining the dynamics of the AMOC and its involvement in climate changes.

\section{Methods Summary}

20-30 tests of G. bulloides and G. inflata (300-355 $\mu \mathrm{m}$ fraction) were analysed for $\delta^{18} \mathrm{O}$ and $\mathrm{Mg} / \mathrm{Ca}$ ratios following published methods ${ }^{11}$, screening for contaminating ferromanganese overgrowths, clay minerals and silicate particles. Analytical precision of $\mathrm{Mg} / \mathrm{Ca}$ ratios based on replicates of foraminiferal standards is $3 \%$. Shell weights show $\mathrm{Mg} / \mathrm{Ca}$ ratios are not affected by dissolution.

Oxygen isotope ratios were determined via gas source mass spectrometry relative to the Vienna Peedee belemnite (VPDB) standard. Analytical precision based on longterm replicates is better than 0.08 ă .

An exponent of $A=0.10$ was used $^{12}$ in the equation: $\mathrm{Mg} / \mathrm{Ca}=B \exp (A \times \mathrm{T})$. Core-top $\mathrm{Mg} / \mathrm{Ca}$ values were calibrated to modern hydrographic data yielding values for $B$ of 0.794 and 0.675 for G. bulloides and G. inflata respectively.

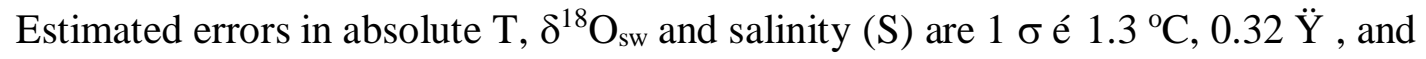
0.8 psu respectively ${ }^{13}$. Estimated errors in relative $\mathrm{T}, \delta^{18} \mathrm{O}_{\mathrm{sw}}$ and $\mathrm{S}$ are $1 \sigma \stackrel{\circ}{1.0}{ }^{\circ} \mathrm{C}, 0.26$ ă and 0.46 psu respectively. These estimates include measurement errors, sample heterogeneity, carbonate ion effects and ice-volume effect uncertainty but ignore calibration errors which should be more constant downcore and changes in the $S-\delta^{18} \mathrm{O}_{\text {sw }}$ 
relationship, which on a regional and larger scale, should affect both species similarly. The introduction of glacial meltwater will result in light $\delta^{18} \mathrm{O}_{\mathrm{sw}}$ values and anomalously low salinities may be reconstructed. The import and subsequent melting of sea-ice south of Iceland will freshen the water column with only a minor change in $\delta^{18} \mathrm{O}_{\text {sw }} ; \delta^{18} \mathrm{O}_{\text {sw }}$ reconstructions may therefore underestimate the surface freshening. Comparison between the G. bulloides and G. inflata data help constrain the relative changes through time.

1. Bond, G. et al., Persistent solar influence on north Atlantic climate during the Holocene. Science 294, 2130-2136 (2001).

2. Bianchi, G.G. \& McCave, I.N. Holocene periodicity in North Atlantic climate and deep-ocean flow south of Iceland. Nature 397, 515-517 (1999).

3. Mayewski, P.A. et al. Holocene climate variability. Quat. Res. 62, 243-255 (2004).

4. Cubasch, U. \& Meehl, G. Projections of future climate change. In Climate Change 2001: The Scientific Basis, J. T. Houghton et al., Eds. (Cambridge Univ. Press, Cambridge, 2001), pp. 525ï 582.

5. Hátún, H., Sando, A.B., Drange, H., Hansen, B., Valdimarsson, H. Influence of the Atlantic subpolar gyre on the thermohaline circulation. Science 309, 1841-1844 (2005).

6. Hansen, B. \& Østerhus, S. North Atlantic-Nordic Seas exchanges. Prog. Oceanogr. 45, 109-208 (2000). 
7. Blindheim, J. \& Østerhus, S. The Nordic Seas, main oceanographic features.

Geophysical Monograph 158, 11-37 (American Geophysical Union, Washington, DC, 2005).

8. Came, R.E., Oppo, D.W., \& McManus, J.F. Amplitude and timing of temperature and salinity variability in the subpolar North Atlantic over the past 10 k.y. Geology 35, 315-318 (2007).

9. Lamb, H.H. Climatic variation and changes in the winds and ocean circulation: The Little Ice Age and the Northeast Atlantic. Quat. Res. 11, 1-20 (1979).

10. Andersen, K.K. et al. High-resolution record of Northern Hemisphere climate extending into the last interglacial period. Nature 431, 147-151 (2004).

11. Barker, S., Greaves, M. \& Elderfield, H. A study of cleaning procedures used for foraminiferal Mg/Ca paleothermometry. Geochem. Geophys. Geosys. 4, 8407-8427 (2003).

12. Barker, S., Cacho, I., Benway, H. \& Tachikawa, K. Planktonic foraminiferal Mg/Ca as a proxy for past oceanic temperatures: a methodological overview and data compilation for the Last Glacial Maximum. Quat. Sci. Rev. 24, 821-834 (2005).

13. Schmidt, G.A. Error analysis of paleosalinity calculations. Paleoceanography 14, 422-429 (1999).

14. Ganssen, G.M. \& Kroon, D. The isotopic signature of planktonic foraminifera from NE Atlantic surface sediments: implications for the reconstruction of past oceanic conditions. J. Geol. Soc. 157, 693-699 (2000). 
15. Cléroux, C., Cortijo, E., Duplessy, J.-C., and Zahn, R. Deep-dwelling foraminifera as thermocline temperature recorders, Geochem. Geophys. Geosys., 8, Q04N11 doi:10.1029/2006GC001474 (2007).

16. Orvik, K.A. \& Niiler, P. Major pathways of Atlantic water in the northern North Atlantic and Nordic Seas toward Arctic. Geophys. Res. Lett. 29, 1896-1900 (2002).

17. NODC_WOA98 data provided by the NOAA/OAR/ESRL PSD, Boulder, Colorado, USA, from http://www.cdc.noaa.gov/

18. Haug, G.H., Hughen, K.A., Sigman, D.M., Peterson, L. \& Röhl, U. Southward migration of the intertropical convergence zone through the Holocene. Science 293, 1304-1308 (2001).

19. Solignac, S., deVernal, A. \& Hillaire-Marcel, C. Holocene sea-surface conditions in the North Atlantic - contrasted trends and regimes in the western and eastern sectors (Labrador Sea vs. Iceland Basin). Quat. Sci. Rev. 23, 319-334 (2004).

20. Rosenheim, B.E., Swart, P.K., Thorrold, S.R., Eisenhauer, A. \& Willenz, P. Salinity change in the subtropical Atlantic: Secular increase and teleconnections to the North Atlantic Oscillation. Geophys. Res. Lett. 29, L02603 doi:10.1029/2004GL021499 (2005).

21. Lund D.C. \& Curry, W.B. Late Holocene variability in Florida current surface density: Patterns and possible causes. Paleoceanography 19, PA4001 doi:10.1029/2004PA001008 (2004).

22. Cléroux, C. et al. Upper water column hydrology changes off Cape Hatteras and Gulf Stream activity over the Holocene. EoS Trans. $A G U, \mathbf{8 8}$ (52), Fall Meet. Suppl. Abstract PP13B-1276. 
23. Häkkinen, S. \& Rhines, P.B. Decline of subpolar North Atlantic circulation during the 1990s. Science 304, 555-559 (2004).

24. Hillaire-Marcel, C., deVernal, A., Bilodeau, G. \& Weaver A. Absence of deep-water formation in the Labrador Sea during the last interglacial period. Nature 410, 10731077 (2001).

25. deMenocal, P.B., Ortiz, J., Guilderson, T. \& Sarnthein, M. Coherent high- and lowlatitude climate variability during the Holocene Warm Period. Science 288, 21982202 (2000).

26. Dickson, R., Lazier, J., Meincke, J., Rhines, P. \& Swift, J. Long-term coordinated changes in the convective activity of the North Atlantic. Prog. Oceanogr. 38, 241295 (1996).

27. Schulz, M., Prange, M. \& Klocker, A. Low-frequency oscillations of the Atlantic Ocean meridional overturning circulation in a coupled climate model. Clim. Past $\mathbf{3}$, 97-107 (2007).

28. Oppo, D.W., McManus, J.F. \& Cullen, J.L. Deepwater variability in the Holocene epoch. Nature 422, 277-278 (2003).

29. Debret, M. et al. The origin of the 1500-year climate cycles in Holocene NorthAtlantic records. Clim. Past 3, 569-575 (2007).

30. Schmidt, M.W., Vautravers, M.J. \& Spero, H.J. Rapid subtropical North Atlantic salinity oscillations across Dansgaard-Oeschger cycles. Nature 443, 561-564 (2006).

Supplementary Information is linked to the online version of the paper at www.nature.com/nature. 
Author Information The authors declare no competing financial interests. Correspondence and requests for materials should be addressed to D.J.R.T. (d.thornalley@ cantab.net).

Author Contributions H.E. and I.N.M. were responsible for initiating the study; D.J.R.T. collected data, performed analyses and interpreted data. The manuscript was written by D.J.R.T. H.E. and I.N.M. contributed equally to the study. All authors contributed to the work at sea on Charles Darwin 159, discussed the results and commented on the manuscript.

Acknowledgements We thank the crew of CD-159; Mervyn Greaves, Angela Huckle and Linda Booth for laboratory assistance; James Rolfe and Mike Hall for stable isotope analyses; John Hillier for the Atlantic base map; Simon Crowhurst, Trond Dokken, Michael Schulz and Luke Skinner for discussions. Radiocarbon dates were run by the NERC radiocarbon laboratory. Labrador Sea data was provided by Anne deVernal. Funding was provided by the NERC RAPID project. 
Fig. 1. Map of study area with a schematic of the main features of the surface circulation in the northeast North Atlantic ${ }^{16}$. Location of core RAPiD-12-1K $\left(62^{\circ} 05.43 \hat{\alpha}\right.$, $17^{\circ} 49.18 \mathrm{~W} ; 1938 \mathrm{~m}$ water depth) marked with a black circle. Continuous arrows show the main branches of the North Atlantic Current: IC, Irminger Current, 1 Sv; FC, Faroe Current, 3.3 Sv; SC, Shetland Current, 3.7 $\mathrm{Sv}^{6}$ which draw water from the subpolar gyre (SPG) and subtropical gyre (STG). Dashed lines show the East Greenland Current (EGC, at least $1.3 \mathrm{~Sv}$ across the ridge ${ }^{6}$ ) and the East Icelandic Current.

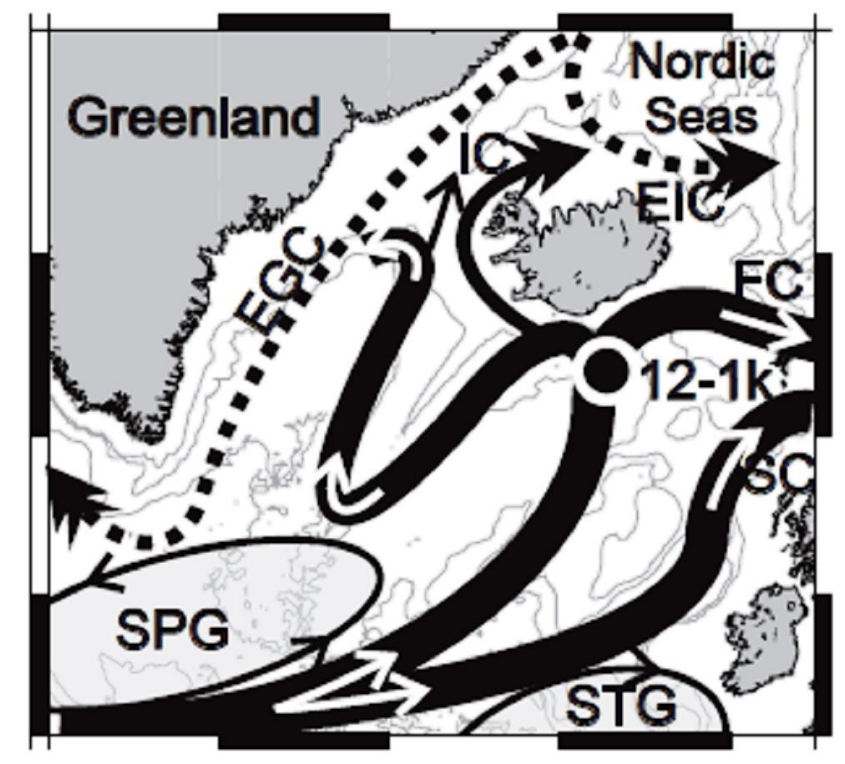


Fig. 2. Proxy records for RAPiD-12-1K. Three-point running means shown in bold. (a) $\mathrm{Mg} / \mathrm{Ca}$-based temperatures and (b) Salinity estimates derived from paired $\mathrm{Mg} / \mathrm{Ca}-\delta^{18} \mathrm{O}$, for near-surface ( $G$. bulloides, red) and sub-thermocline ( $G$. inflata, blue) waters. Also shown is a scale bar for $\delta^{18} \mathrm{O}_{\text {sw }}$ values, corrected for whole ocean ice volume changes. (c, d) Proxies for upper water column stratification (stratification increases upwards) based on: (c) the $\delta^{18} \mathrm{O}$ difference between $G$. bulloides and G. inflata; (d) the inferred water density difference between $G$. bulloides and $G$. inflata, calculated using derived temperatures and salinities.

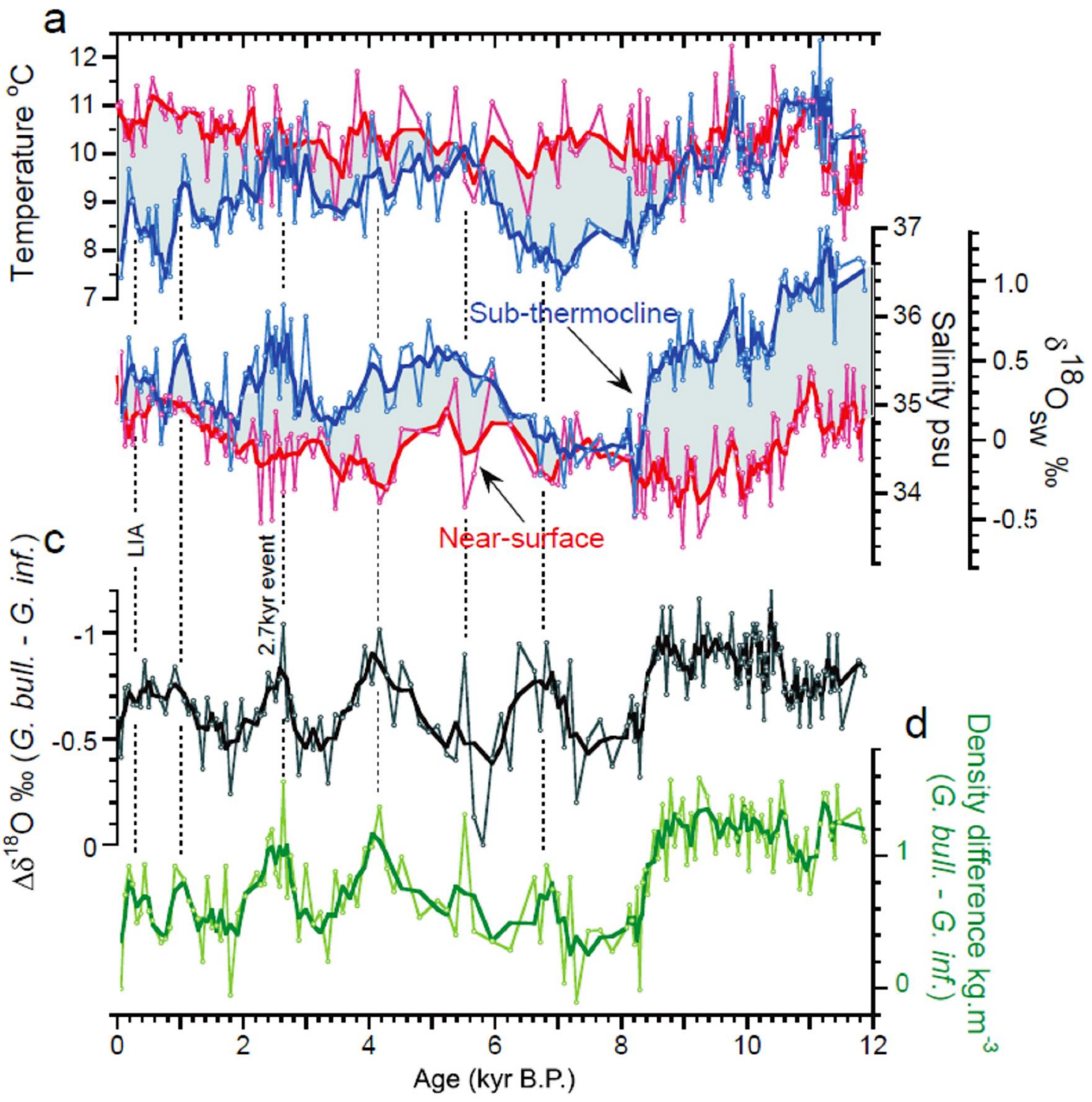


Fig. 3. Records of changing gyre properties. (a) Linear detrended temperature anomalies from the west coast of Africa (green line and circles) ${ }^{25}$. Warmer temperatures are caused by either decreased upwelling or decreased advection of subpolar waters into the eastern Atlantic during weak subpolar gyre circulation. (b) Salinity estimates from $G$. inflata for RAPiD-12-1K (blue line and circles); and dinocyst assemblage salinity estimates from the central Labrador Sea (subpolar gyre) ${ }^{19}$ on a reversed axis (red squares; red triangles are outliers not included in the three point mean - red line). Grey shaded regions are periods of global rapid climate change ${ }^{3}$.

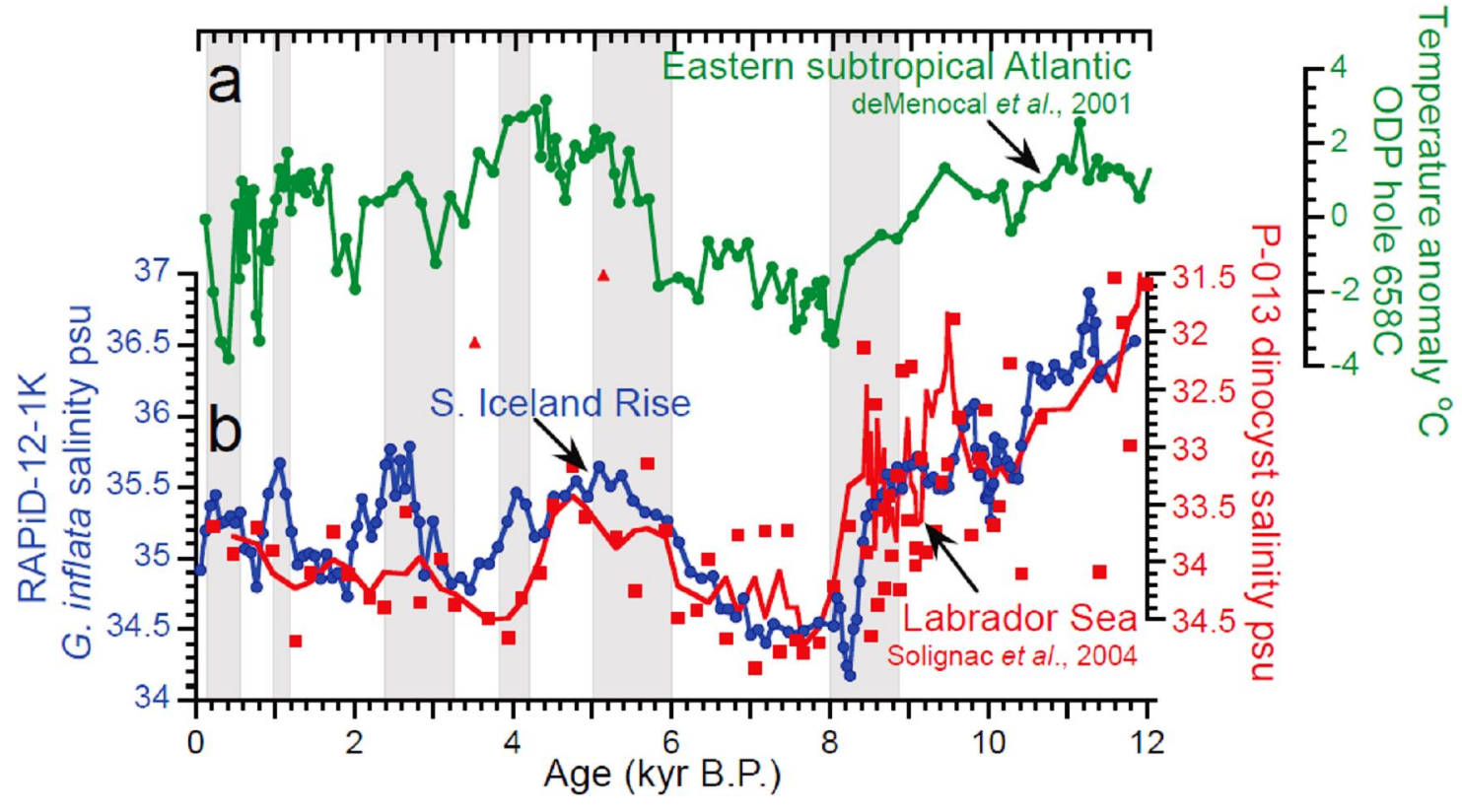

